Open Access

\title{
Entrepreneurial intention of international business students in Viet Nam: a survey of the country joining the Trans-Pacific Partnership
}

\author{
Cuong Nguyen®D
}

Correspondence:

Cuongnguyen4b@gmail.com Industrial University of Ho Chi Minh City, 12 Nguyen Van Bao Street Ward 4 Go Vap District, Ho Chi Minh City, Viet Nam

\begin{abstract}
This study aims to investigate entrepreneurial intention among international business students in Viet Nam as it is on the way to approve The Trans-Pacific Partnership (TPP). The theory of planned behavior (TPB) (Ajzen, 1991) is used to assess the determinants of entrepreneurial intention of Vietnamese students who major in international business study. An exploratory factor analysis and multiple regressions are used to examine the responses from 372 final year students. The results confirm that attitude toward entrepreneurship and perceived behavior control are positively related to entrepreneurial intention. Subjective norm fails to generate a significant impact on entrepreneurial intention. Entrepreneurial intention is significantly influenced by two components of TPB model $\left(R^{2}=0.307\right)$ which are attitude toward entrepreneurship $(\beta=0.292)$ and perceived behavior control $(\beta=0.408)$.
\end{abstract}

Keywords: Entrepreneurial intention, Ajzen's planned behavior theory (TPB), International business students, Trans-Pacific Partnership (TPP)

\section{Background}

The Trans-Pacific Partnership (TPP) is a high-standard trade agreement between twelve countries which are Australia, Canada, Japan, Malaysia, Mexico, Peru, USA, Vietnam, Chile, Brunei, Singapore and New Zealand (Ministry of Industry and Trade of Viet Nam 2016). The Trans-Pacific Partnership (TPP) aims to promote social and economic development among participating countries by removing tariff and non-tariff barriers, protect workers and preserve the environment, promote transparency, participation and accountability in government decision-making, fighting corruption and protect digital freedom. From Vietnamese perspective, the Trans-Pacific Partnership (TPP) is a great deal for the country's social and economic development, especially in term of international trade, call for foreign direct investment and the development of local small and medium enterprises (Government Office of Vietnam 2016). Vietnamese government has a plan to present the TPP for Vietnamese National Assembly to verify in July 2016. Ministry of Industry and Trade of Viet Nam predicts that the TPP will bring many benefits for Vietnamese international trade such as $50 \%$ tariff deduction to the USA which is approximately one billion US dollars for the first year joining TPP.

(c) The Author(s). 2017 Open Access This article is distributed under the terms of the Creative Commons Attribution 4.0 International License (http://creativecommons.org/licenses/by/4.0/), which permits unrestricted use, distribution, and reproduction in any medium, provided you give appropriate credit to the original author(s) and the source, provide a link to the Creative Commons license, and indicate if changes were made. 
Textile industry expects a growth rate of $30 \%$ per year (Ministry of Industry and Trade of Viet Nam 2016). Tariff reduction is about $60 \%$ to the USA and growth rate is expected as $25 \%$ per year for Vietnamese shoe-making industry. Joining TPP is a great opportunity for Viet Nam to intergrade into global supply chain because the TPP accounts for 40\% value of global Gross Domestic Products and 30\% value of global trade. As a result, Vietnamese government has a strong commitment to promote domestic entrepreneurship in general and small and medium enterprises in international trade in particular (Pham, 2016). In order to promote start-ups, it is significant to study what determinants affect the intention to become entrepreneur among business students in Viet Nam. Initially, entrepreneurial intention should be treated as a crucial step in establishment process of new ventures leading to entrepreneurial activities. Entrepreneurial intention captures a state of mind that directs individuals' focus to achieve a goal or something (Bird 1988). Individuals with intention to start a business are likely to carry it out (Ajzen, 1991). Choo and Wong (2006) confirm that intention is the single best predictor of entrepreneurial behavior. Henley (2007) states that entrepreneurship is an intentional activity, in that for many those intentions are formed at least a year in advance of new venture creation suggesting a link between entrepreneurship and intention. The significance of examining entrepreneurial intention has a rich literature with many recent empirical studies in the field of entrepreneurship (Lee et al. 2011; Siu and Lo 2013). The main objective of this paper is to apply the Theory of Planned Behavior (Ajzen, 1991 to examine the entrepreneurial intention among international business students in the context of joining the Trans-Pacific Partnership (TPP). This paper includes four parts which are introduction, literature review, research methodology, results and conclusion. The target group is the final year students who study international business in Viet Nam. Sample size is 372 international business students from different university in Ho Chi Minh City in Viet Nam. Entrepreneurial intention is the first step to understand the whole process to start up a new business. Entrepreneurial intention is central to understand the entrepreneurship process because they form the underpinnings of new organizations (Bodewes et al., 2010). Entrepreneurial intention is defined as one's willingness in undertaking entrepreneurial activity, or in other words become self-employed. The opposition of self-employed is becoming a waged or salaried individual (Tkachev and Kolvereid 1999). Pihie (2009) defines intention as a state of mind or attitude which influences entrepreneurial behavior. Choo and Wong (2006) define entrepreneurial intention as the search for information that can be used to help fulfill the goal of venture creation. Entrepreneurial intention can generally be defined as a conscious awareness and conviction by an individual that they intend to set up a new business venture and plan to do so in the future (Bird, 1988; Thompson, 2009). Previously, researchers have abundantly focused on the topic of intent. In particular, the decision by an individual to become an entrepreneur has been researched under the terms "entrepreneurial intent" and "entrepreneurial intention" but other terms are also found, such as "entrepreneurial becoming", "entrepreneurial decision-making", "entrepreneurial entry", and others. There are two basic streams of research which are psychological models and non-psychological models. However, non-psychological approaches did not provide satisfactory results (DePillis and Reardon 2007; Krueger et al. 2000). The low explanatory power of non-psychological approaches lead to new trends of research. The new trends focus on behavioral intention models focusing on "attitude 
approach" or "psychological approach" that go beyond demographics and personality traits determining the "conscious" and "voluntary" act of new venture creation (Bui, 2011). According to Ajzen (1991), researchers who have utilized these models believe that the actual behavior is determined by intentions to perform entrepreneurial behavior which greatly depend on the personal attitudes toward this behavior. The more level of favorable attitude would increase the intention to be an entrepreneur. As a result, the "attitude approach" is much more rigorous to predict entrepreneurial intention than the demographic and personality trait approach (Krueger et al. 2000). Currently, there are two popular avenues informing number of theoretical frameworks, Shapiro's entrepreneurial event and Ajzen's theory of planned behavior (Astuti and Martdianty, 2012; Carey et al. 2010; Tegtmeier, 2006; Van Gelderen et al., 2008).

Remarkably, this extant body of knowledge is dominantly Western, Anglo-Saxon, mainly (Bullough et al. 2014; Carey et al., 2010; Cassar, 2007; Cha and Bae, 2010; Crant, 1996; De Jorge-Moreno et al. 2012; Paço et al. 2011; Raijman, 2001; Souitaris et al. 2007; Tegtmeier, 2006; Tomski, 2014; Turker and Sonmez Selcuk, 2009; Van Gelderen et al., 2008), and increasingly European (Castellano et al. 2014; Llouga et al. 2013; Nyock et al. 2013; Tounés, 2006; Varela Villegas et al. 2011), and/or cross-cultural (Cassar, 2007; Engle et al. 2011; Laspita et al. 2012; Liñán and Chen, 2009; Linón et al. 2013; Moriano et al. 2012; St-Jean et al., 2014). Empirical studies from Asia have appeared in recent years, from China (Bernhofer and Han, 2014; Siu and Lo, 2013), Pakistan (Azhar et al. 2010), India (Wei, 2007), and Viet Nam (Tran and Santarelli 2014; Mai, 2016)

In Shapero's Entrepreneurial Event Model (Shapero, 1975), it considers firm creation as the result of the interaction among contextual factors, which would act through their influences on the individual's perceptions. Shapero lists three dimensions that determine entrepreneurial intention, namely "Perceived desirability," "Perceived feasibility," and "Propensity to act". Shapero emphasizes the importance of perception in predicting the intention to act in some specific ways. The perception requires that the behavior must be desirable and feasible and a clear propensity to act the behavior. The three components of Entrepreneurial Event are explained as follows:

- Perceived desirability refers to the degree to which he/she feels attraction for a given behavior (to become an entrepreneur).

- Perceived feasibility is defined as the degree to which people consider themselves personally able to carry out certain behavior. The presence of role models, mentors or partners would be a decisive element in establishing the individual's entrepreneurial feasibility level.

- Propensity to act refers to an individual's willingness to act on decision.

The three above perceptions are determined by cultural and social factors, through their influence on the individual's values system (Shapero, 1975). Many academicians confirm the usefulness of this model in prediction of entrepreneurial intention. Krueger and Brazeal (1994) confirms that three components of this model explained approximately 50 percent of the variance in entrepreneurial intentions. The best predictor in that research was perceived feasibility. Recently, Daim et al. (2016) provides insight into the entrepreneurial intensions of students in terms of genders and country of residence 
differences. The paper explores perceived feasibility and desirability for students in 10 countries. The entrepreneurship role is gender tested against desirability and feasibility. The results indicate that gender impacts entrepreneurship intention and the way it impacts is influenced by which country the students are from (Daim et al. 2016). Furthermore, Krueger et al. (2000) modifies the model with two more components which are specific desirability and perceived self-efficacy. Krueger studies the significance to understand the self-efficacy in relation to entrepreneurial intention and he also concluded that entrepreneurial usually ignore the concept of self-efficacy in entrepreneurial researches. Self-efficacy theory explains what peoples' beliefs about their capabilities to produce effects are. A strong sense of self-efficacy strengthens human accomplishments and personal well-being in many ways (Bandura, 1977). Figure 1 illustrates Krueger and Shapero's model:

From another perspective, the Theory of Planned Behavior model is the most widely used to research on entrepreneurial intention (Liñán and Chen 2009). In this model, there are three conceptually independent determinants of intention toward entrepreneurship, namely attitudes toward entrepreneurship, subjective norms, and perceived behavior control (Ajzen, 1991). Figure 2 illustrates the components of this model.

Attitude toward performing behavior refers to perceptions of personal desirability to perform the behavior (Ajzen, 1991). It depends on the expectations and beliefs about personal impacts of outcomes resulting from the behavior. A person's attitude toward behavior represents evaluation of the behavior and its outcome. Attitude toward entrepreneurship refers to the personal desirability in becoming an entrepreneur (Kolvereid 1997). As a result, the more expectations and beliefs toward self-employment reflect a favorable attitude toward entrepreneurship. Financial security was the most outstanding variable that made up for the attitude toward entrepreneurial intention (Gelderen, 2008). Many studies confirm a positive relationship between attitude and behavioral intention (Kolvereid 1997; Krueger et al., 2000; Autio et al., 2001; Gelderen et al. 2008; Bodewes et al. 2010; Tegtmeier, 2012; Yang, 2013). In a recent study in China, Yang (2013) confirms that attitude represented the most effective predictor of entrepreneurial intention. In contrast, Zhang (2015) confirms a surprise result from a study conducted in the USA that attitude fails to generate a significant impact on entrepreneurial intention. It is clear to see that there are differences in the results of the impact of attitude toward entrepreneurship. Hence, the first hypothesis is developed as H1: Attitude toward entrepreneurship is positively related to entrepreneurial intention.

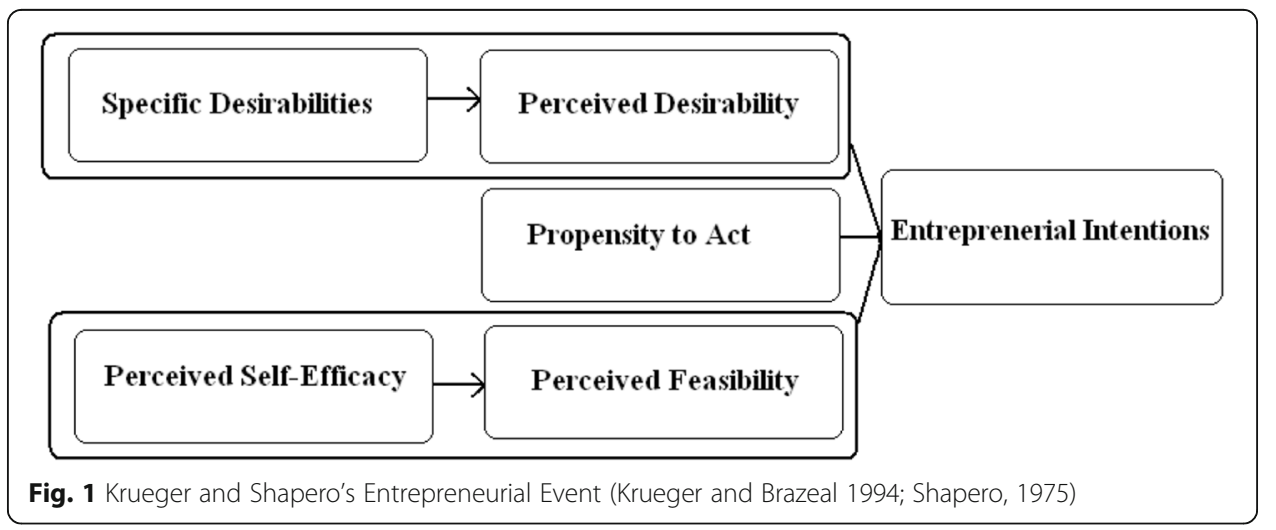




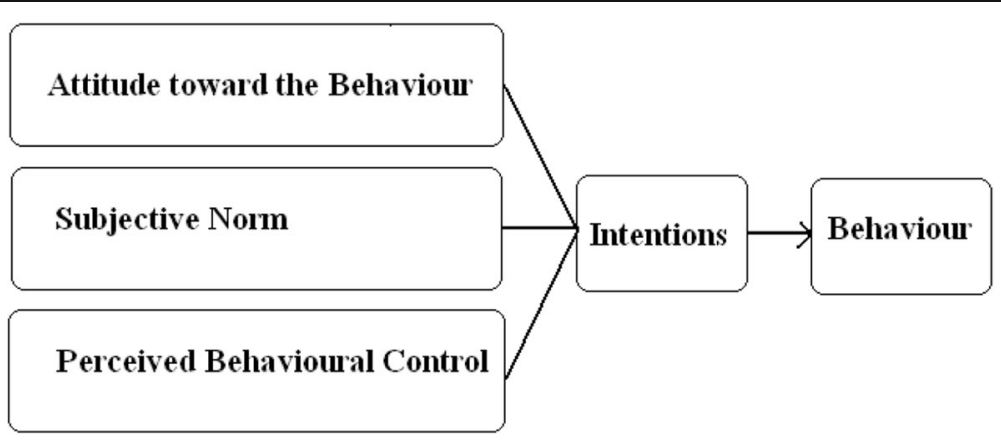

Fig. 2 Ajzen's Theory of Planned Behaviour (Ajzen, 1991)

Subjective norms refer to the person's perception of the social pressures for or against performing the behavior in question (Ajzen, 1991). Subjective norm reflects an individual's perception that most people of importance think that he or she should not perform the behavior (Ajzen, 1991). The Theory of Planned Behavior assumes that subjective norm is a function of beliefs. In this sense, when a person believes that his or her referents think that behavior should be performed, and then the subjective norm will influence his or her intention to perform that particular behavior. Many studies confirm that subjective norm is positively related to intention (Covered, 1996, Ajzen and Driver, 1992; Krueger et al., 2000; Autio et al., 2001; Wu, 2008; Tegtmeier, 2012; Yang, 2013; Zhang, 2015). As a result, the second hypothesis is stated as H2: Subjective norm is positively related to entrepreneurial intention.

Perceived behavior control reflects the perceived ability to execute target behavior (Ajzen, 1991). It relates to a person's perception on the degree of easiness and difficulties in performing such behavior, and it is assumed to reflect past experience as well as anticipated obstacles (Ajzen and Driver, 1992). This factor is influenced by perceptions of access to necessary skills, resources and opportunities to perform the behavior. If a person feels that he or she has control over the situational factors, he or she may promote the intention to perform the particular behavior. In contrast, if that person does not have control over the circumstances, he or she may not have any or less intention to perform the particular behavior. In other words, perceived behavior controls and influences intention to perform behavior. Many researchers prove that there is a relationship between perceived behavior control and behavioral intention (Ajzen and Driver, 1992; Mathieson, 1991). Many studies propose a significant relationship between perceived behavior control and entrepreneurial intention (Covered, 1996; Krueger et al., 2000; Autio et al., 2001; Solitaries et al., 2006; Gelderen et al. 2008; Tegtmeier, 2012; Yang, 2013; Zhang, 2015). The third hypothesis is written as H3: Perceived behavior control is positively related to entrepreneurial intention.

\section{Results and discussion}

Exploratory factor analysis (EFA) using varimax rotation method with the application of Kaiser-Meyer-Olkin measure (KMO) and Barltlett's test of sphericity show the good results of reliability test for the dependent variable and independent variables as the following tables (Table 1): 
After checking reliability, the next step is to conduct Exploratory Factor Analysis. Gerbing suggest that any questions has factor loading is less than 0.5 will be removed (Gerbing and Anderson 1988). Extraction method is principal components with rotation method is Varimax and only take components when eigenvalue is greater or equal to 1 . The result shows that $\mathrm{KMO}$ is 0.845 and sig $=0.000$ show the appropriateness to apply Exploratory Factor Analysis for 15 questions of independent variables (Table 2).

The result shows that there are three components extracted where eigenvalue is equal to 1.759 and cumulative variance is $59.27 \%$. Component 1 includes question 10 to question 15 which belongs to Attitude Toward Entrepreneurship. Component 2 includes questions 1 to question 5 which belongs to Perceived Behavioral Control. Component 3 includes question 6 to question 9 which belong to Subjective Norm (Table 3).

Multicollinearity test requires checking Pearson Correlation between independent variables which are attitude toward entrepreneurship (ATE), perceived behavior control $(\mathrm{PBC})$, and subjective norm $(\mathrm{SN})$. The result shows that correlation between independent variables is 0.000 which means they are totally independent so they qualify the requirements of Multiple Regression Analysis (Table 4).

The goodness of fit for this multiple regression mode show adjusted $R^{2}=0.348$ which is less than $R^{2}=0.354$ (Table 5).

This result proves that this multiple regression model fits the data and $35.4 \%$ of the variance in the data is explained by this model. In $F$ test from ANOVA table, $F=66.786$ and Sig $=0.000$. This means this multiple regression fits the data (Table 6).

The result also shows that attitude toward entrepreneurship and perceived behavior control are significant at $1 \%$, and Subjective norm is not significant at any level (Table 7).

From the results above, it is now possible to conclude the hypotheses as the following:

H1: Attitude toward entrepreneurship is positively related to entrepreneurial intention is supported.

H2: Subjective norm is positively related to entrepreneurial intention is not supported.

H3: Perceived behavior control is positively related to entrepreneurial intention is supported.

\section{Conclusions}

The coefficient or $\beta$ of attitude toward entrepreneurship is 0.292 and hypothesis $H 1$ : Attitude toward entrepreneurship is positively related to entrepreneurial intention is supported. This result is consistent with other previous studies (Gerbing and Anderson 1988; Kolvereid, 1997; Krueger and Brazeal 1994; Bodewes et al. 2010; Tegtmeier, 2012; Yang, 2013). In contrast, Zhang (2015) confirmed that attitude toward entrepreneurship fails to generate a significant impact on entrepreneurial intention in a search conducted in the USA.

The findings did not support the H2: Subjective norm is positively related to entrepreneurial intention. This result is inconsistent with many previous studies (Gerbing and Anderson 1988; Autio et al. 2001; Bodewes et al. 2010; Tegtmeier, 2012; Yang, 2013) that subjective norm has a positive relationship with entrepreneurial intention. However, a recent study from Robledo et al. (2015) also confirms that subjective norm did have any influence on entrepreneurial intention. In Vietnamese context, Khuong and An (2016) also confirm that subjective norm did not have any influence on 
Table 1 Cronbach's Alpha Checking

\begin{tabular}{llc}
\hline Given names & Number of Items & Cronbach's Alpha \\
\hline Entrepreneurial intention (EI) & 6 & 0.856 \\
Perceived behavioral control (PBC) & 5 & 0.802 \\
Subjective norm (SN) & 4 & 0.739 \\
Attitude toward entrepreneurship (ATE) & 6 & 0.866 \\
\hline
\end{tabular}

entrepreneurial intention of Vietnamese students. As a result, subjective norm must be further researched to test its influence on entrepreneurial intention.

The finding supports hypothesis H3: Perceived behavior control is positively related to entrepreneurial intention and it has coefficient or $\beta$ is equal to 0.408 . This result is consistent with many previous studies (Gerbing and Anderson 1988; Kolvereid, 1997; Krueger et al. 2000; Bodewes et al. 2010; Tegtmeier, 2012; Yang, 2013; Zhang, 2015). In this research, perceived behavior control remains as the best predictor for entrepreneurship intention. Previous studies also confirmed that perceived behavior control is the best predictor for entrepreneurship intention (Krueger et al. 2000, Linan et al. 2005; Zhang, 2015).

Remarkably, the results only confirm there are only two factors from the Ajzen model are significant contributors to explain entrepreneurial intention $\left(R^{2}=.354, F=66.786\right.$, sig $=.000$ ). Subjective norm fails to generate a positive relationship with entrepreneurial intention. The result has once again confirmed the appropriateness of using Theory of Planned Behavior to predict entrepreneurial intention. The $R^{2}$ of this study is 0.354 which it is consistent with many previous studies such as 0.543 from Krueger's model (Krueger and Brazeal 1994); 0.32 from Davidsson's study (Davidsson, 1995); 0.301 in Finland; 0.353 in Stanford; 0.241 in Colorado (Autio, 2001). Recently, Yang established that $R^{2}$ is 0.49 in China (Yang, 2013). Tegtmeier (2012) established that $R^{2}$ is 0.446 in Germany. In a study in the USA, Zhang (2015) established that $R^{2}$ is 0.426 .

The objective of this research is to identify what factors affect entrepreneurial intention of international business students in Viet Nam. The findings should be used to promote entrepreneurial activities in international trade after Viet Nam joining Trans-Pacific Partnership. The results show that there are only two significant contributors toward entrepreneurial intention which are perceived behavioral control and attitude toward entrepreneurship as applying Aspen's model for international business students in Viet Nam. In order to increase perceived behavioral control, the Vietnamese government should provide entrepreneurial incubation programs in international business studies for final year and graduate students. Vietnamese universities and business schools which offer courses in international business also should encourage students to participate in entrepreneurial activities during the courses. The more experiences and practical exposure of students to entrepreneurial activities in international business industry will increase student's perceived behavioral control over start-up process. As a

Table $2 \mathrm{KMO}$ and Bartlett's Test

\begin{tabular}{lll}
\hline KMO and Bartlett's Test & & \\
\hline Kaiser-Meyer-Olkin measure of sampling adequacy & & 0.845 \\
Bartlett's Test of Sphericity & Approx. $X^{2}$ & 2150.502 \\
& df & 105 \\
& Sig. & 0.000 \\
\hline
\end{tabular}


Table 3 Rotated component matrix

\begin{tabular}{llll}
\hline Rotated component matrix & & & \\
\hline & \multicolumn{2}{l}{ Component } & \\
\cline { 2 - 3 } & 1 & & \\
\hline Q14 & 0.815 & & \\
Q12 & 0.788 & & \\
Q11 & 0.785 & & \\
Q10 & 0.777 & & \\
Q13 & 0.761 & & \\
Q15 & 0.646 & 0.818 & \\
Q4 & & 0.782 & \\
Q2 & & 0.778 & 0.815 \\
Q3 & & 0.702 & 0.745 \\
Q1 & & 0.575 & 0.732 \\
Q5 & & & 0.637 \\
Q7 & & & \\
Q8 & & & \\
Q6 & & & \\
Q9 & & & \\
\hline
\end{tabular}

Extraction method: principal component analysis

Rotation method: Varimax with Kaiser Normalization ${ }^{a}$

${ }^{a}$ Rotation converged in four iterations

result, their entrepreneurial intention also increases and it leads to the increasing startups in international business after Viet Nam officially verifies the Trans-Pacific Partnership. In addition, the Vietnamese government must actively improve attitude toward entrepreneurship among international business students. Successful stories of entrepreneurs in international business will inspire students think about start up. The advantages of the Trans-Pacific Partnership to start up in small and medium business should be widely communicated to students in order to promote a positive attitude toward entrepreneurship. Moreover, the promising results of starting-up in international business can increase entrepreneurial intention of students to officially establish an international business company rather than looking for salaried jobs.

Table 4 Correlation between independent variables

\begin{tabular}{llccc}
\hline Correlations & & & & \\
\hline PBC & Pearson Correlation & 1 & $0.307^{\mathrm{a}}$ & ATE \\
& Sig. (two-tailed) & & 0.000 & $0.334^{\mathrm{a}}$ \\
& $\mathrm{N}$ & 370 & 370 & 0.000 \\
SN & Pearson Correlation & $0.307^{\mathrm{a}}$ & 1 & 370 \\
& Sig. (two-tailed) & 0.000 & & $0.274^{\mathrm{a}}$ \\
& $\mathrm{N}$ & 370 & 372 & 0.000 \\
ATE & Pearson Correlation & $0.334^{\mathrm{a}}$ & $0.274^{\mathrm{a}}$ & 372 \\
& Sig. (two-tailed) & 0.000 & 0.000 & 1 \\
& $N$ & 370 & 372 & 372 \\
\hline
\end{tabular}

${ }^{a}$ Correlation is significant at the 0.01 level (two-tailed) 
Table 5 Model Summary

\begin{tabular}{lllll}
\hline Model summary & & & & \\
\hline Model & $R$ & $R^{2}$ & Adjusted $R^{2}$ & Std. error of the estimate \\
\hline 1 & $0.595^{\mathrm{a}}$ & 0.354 & 0.348 & 1.06246 \\
\hline
\end{tabular}

apredictors: (Constant), ATE, SN, PBC

\section{Methods}

This paper is an exploratory quantitative research which uses Exploratory Factor Analysis and Multiple Regression Analysis to test the hypotheses. The respondents are final year students who major in international business studies in Ho Chi Minh city. The respondents come from Ho Chi Minh University of Industry, Economic University of Ho Chi Minh city and Foreign Trade University. A pilot study was conducted with 25 final year students who come from Faculty of Commerce and Tourism of Ho Chi Minh University of Industry. This pilot study aims to correct and clarify any mistakes or any misunderstandings in questionnaire survey because the questionnaire was in English. Totally, 400 samples were delivered but only 372 samples were qualified to use and the correct responding rate was 93\% (Appendix). Overall, 55.1\% of the respondent were female students and $44.9 \%$ were male students. The questionnaire uses a seven Likert scale. Respondents rate their agreeableness with the statements in a seven Likert scale. The scale increases from " 1 " which is totally disagree to "7" which means totally agree with the statements. Middle point "4" indicates neutral status with the statements. Linen and Chen suggest that it would be much more rigorous to evaluate the level of intention by applying Likert-type scales with seven items because intention is generally viewed as a "complex cognitive trait" (Liñán and Chen 2009).

From question 1 to question 5, these questions measure perceived behavioral control (PBC) which is one of three independent variables in this study. These questions were developed from Autio's questionnaire (Autio et al. 2001), but they have been modified according to the context of this paper. From question 6 to question 9, they measure subjective norm $(\mathrm{SN})$ which is the second independent variable and they were also modified from Audio's questionnaire (Autio et al. 2001). From question 10 to question 15, these questions measure attitude toward entrepreneurship (ATT) and it is the last independent variable.

From question 16 to question 21, they aim to measure entrepreneurial intention (EI) which is the ultimate dependent variable in this research. Krueger (1993) use a dichotomous variable with a Yes/No statement: "Do you think you'll ever start a business?." Davidsson (1995) used a different approach which employed an operationalization of intent on an index of three questions such as "Have you ever considered founding your own firm?," "How likely do you consider it to be that within one year from now you'll

Table 6 ANOVA

\begin{tabular}{lllllll}
\hline ANOVA $^{a}$ & & & & & \\
\hline Model & & Sum of squares & df & Mean square & F & Sig. \\
\hline 1 & Regression & 226.171 & 3 & 75.390 & 66.786 & $0.000^{\mathrm{b}}$ \\
& Residual & 413.152 & 366 & 1.129 & & \\
& Total & 639.323 & 369 & & \\
\hline
\end{tabular}

${ }^{\mathrm{a}}$ Dependent Variable: El

bPredictors: (Constant), ATE, SN, PBC 
Table 7 Coeffients

\begin{tabular}{|c|c|c|c|c|c|c|}
\hline \multicolumn{7}{|c|}{ Coefficients $^{a}$} \\
\hline \multicolumn{2}{|c|}{ Model } & \multicolumn{2}{|c|}{ Unstandardized coefficients } & \multirow{2}{*}{$\begin{array}{l}\text { Standardized coefficients } \\
\beta\end{array}$} & \multirow[t]{2}{*}{$t$} & \multirow[t]{2}{*}{ Sig. } \\
\hline & & $\beta$ & Std. error & & & \\
\hline \multirow[t]{4}{*}{1} & (Constant) & 0.530 & 0.344 & & 1.539 & 0.125 \\
\hline & PBC & 0.473 & 0.053 & 0.408 & 8.887 & 0.000 \\
\hline & SN & 0.049 & 0.045 & 0.049 & 1.097 & 0.273 \\
\hline & ATE & 0.372 & 0.058 & 0.292 & 6.426 & 0.000 \\
\hline
\end{tabular}

be running your own firm?," and "How likely do you consider it to be that within five years from now you'll be running your own firm." Reitan applied a similar approach which using an index measure based on short term view and long term intentions and also on the trade-off between running one's own firm and being employed by other people. In this paper, six questions from 16 to 21 measure Entrepreneurial Intention (EI).

\section{Limitations and further research}

This study has three main limitations that offer opportunities for further research. Firstly, the target of this research only focuses on the intention rather than on actual start-up decisions. There could be a gap between graduate's perception and actual action. Entrepreneurial intention is only measured at current point in time so it is not really sure that students' entrepreneurial intention may or may not change a few years later. This assumption may suggest that further research should provide more accurate methodologies to measure entrepreneurial intention. Secondly, data for this research was only collected in Ho Chi Minh City of Viet Nam so it lacks of generalizability for the whole country of Viet Nam. Currently, Ho Chi Minh City is one of the most dynamic business hubs in Viet Nam, but final year students in other cities like Ha Noi, Hai Phong, or Da Nang may think differently about entrepreneurial intention. Finally, this study lacks of a dramatically innovative methodology. Azjen's model has been employed to measure entrepreneurial intention in many times worldwide and there is very rich literature review on the topic. This fact calls for an innovative methodology to measure entrepreneurial intention in more accurate and rigorous ways.

\section{Appendix 1: entrepreneurial intention survey}

Question 1: I am confident that I would be successful if I started my international business company.

Question 2: I have the skills and capabilities required to succeed as an international business entrepreneur.

Question 3: I have the necessary resources to start my international business company successfully.

Question 4: I have enough working experience to start my international business company.

Question 5: It would be easy for me to start my international business company.

Question 6: I know many people in my university who have successfully started up their firms in international business industry. 
Question 7: In my university, people are actively encouraged to pursue their own ideas to start up in international business industry.

Question 8: In my university, you can meet many people with good ideas to start tp in international business industry.

Question 9: In my university, there is a well-functioning support infrastructure in place to support the start-up international business industry.

Question 10: Becoming an international business entrepreneur will give me autonomy and freedom.

Question 11: Establishing a firm in international business will make my job more challenging and interesting.

Question 12: Starting up a firm in international business will help me earn a lot of money.

Question 13: Becoming an international business entrepreneur will provide me more opportunities to develop my expertise.

Question 14: Becoming an international business entrepreneur will make me more confident.

Question 15: Becoming an international business entrepreneur will give me more power.

Question 16: I always want to be an entrepreneur in international business.

Question 17: Becoming an international business entrepreneur is one of my most important career objectives.

Question 18: I had a serious consideration to start up in international business.

Question 19: I have a detailed plan to start up my company in international business.

Question 20: I will start up my company in international business within 1 year from now.

Question 21: I will start up my company in international business within 5 years from now.

Competing interests

The author declares that there are no competing interests.

\section{Publisher's Note}

Springer Nature remains neutral with regard to jurisdictional claims in published maps and institutional affiliations.

Received: 18 June 2016 Accepted: 4 March 2017

Published online: 23 March 2017

\section{References}

Ajzen, I. (1991). The theory of planned behaviour. Organizational Behaviour and Human Decision Process, 50(2), 179-121.

Astuti, R. D., \& Martdianty, F. (2012). Students' entrepreneurial intentions by using theory of planned behavior. South East Asian Journal of Management, 6(2), 100-143.

Autio, K., Klofsten, P., \& Hay. (2001). Entrepreneurial intent among students in Scandinavia and in the USA. Enterprise and Innovation Management Studies, 2(2), 145-160.

Azhar, A., Javaid, A., Rehman, M., \& Hyder, A. (2010). Entrepreneurial intentions among business students in Pakistan. Journal of Business Systems, Governance \& Ethics, 5(2), 13-21.

Bandura, A. (1977). Social learning theory. New York: General Learning Press.

Bernhofer, L., \& Han, Z. (2014). Contextual factors and their effects on future entrepreneurs in China: a comparative study of entrepreneurial intentions. International Journal of Technology Management, 65(1-4), 125-150. doi:10.1504/ IJTM.2014.060955.

Bird, B. (1988). Implementing entrepreneurial ideas: the case for intention". Academy of Management Review, 13(3), 442-453.

Bodewes, W., Van Gelderen, M., Brand, M. J., Van Praag, M., Poutsma, E., \& Van Gils, A. (2010). Explaining entrepreneurial intentions by means of the theory of planned behaviour. Career Development International, 13(No. 6), 538-559.

Bui, H, Thi Lan. (2011). Entrepreneurial intention among vietnamese business students: identifying key factors influencing their intention of new venture formation. International Vision, CFVG, Vol. 15. 
Bullough, A., Renko, M., \& Myatt, T. (2014). Danger zone entrepreneurs: the importance of resilience and self-efficacy for entrepreneurial intentions. Entrepreneurship: Theory \& Practice, 38(3), 473-499. doi:10.1111/etap.12006.

Carey, T. A., Flanagan, D. J., \& Palmer, T. B. (2010). An examination of university student entrepreneurial intentions by type of venture. Journal of Developmental Entrepreneurship, 15(4), 503-517.

Cassar, G. (2007). Money, money, money? A longitudinal investigation of entrepreneur career reasons, growth preferences and achieved growth. Entrepreneurship \& Regional Development, 19(1), 89-107. doi:10.1080/ 08985620601002246.

Castellano, S., Maalaoui, A., Safraou, I., \& Reymond, E. (2014). Linking intuition and entrepreneurial intention: a comparative study among French and US student entrepreneurs. International Journal of Entrepreneurship \& Innovation Management, 18(1), 23-44. doi:10.1504/IJEIM.2014.062787.

Cha, M.-S., \& Bae, Z.-T. (2010). The entrepreneurial journey: from entrepreneurial intent to opportunity realization. Journal of High Technology Management Research, 21(1), 31-42. doi:10.1016/j.hitech.2010.02.005.

Choo, S., \& Wong, M. (2006). Entrepreneurial intention: triggers and barriers to new venture creations in Singapore. Singapore Management Review, 28 i, 47-64.

Crant, J. M. (1996). The proactive personality scale as a predictor of entrepreneurial intentions. Journal of Small Business Management, 34(3), 42-49.

Daim, T., Dabic, M., \& Bayraktaroglu, E. (2016). Students' entrepreneurial behavior: international and gender differences. Journal of Innovation and Entrepreneurship, 5(1), 1-22.

Davidsson, P. (1995). Determinants of entrepreneurial intentions. Paper presented at the RENT IX workshop in entrepreneur research, Piacenza, Italy.

De Jorge-Moreno, J., Castillo, L. L., \& Triguero, M. S. (2012). The effect of business and economics education programs on students' entrepreneurial intention. European Journal of Training \& Development, 36(4), 409-425. doi:10.1108/ 03090591211220339.

DePillis, E., \& Reardon, K. K. (2007). The influence of personality traits and persuasive messages on entrepreneurial intention. Career Development International, 12(4), 382-396.

Engle, R. L., Schlaegel, C., \& Dimitriadi, N. (2011). Institutions and entrepreneurial intent: a cross- country study. Journal of Developmental Entrepreneurship, 16(2), 227-250.

Gerbing, D. W., \& Anderson, J. C. (1988). An updated paradigm for scale development incorporating unidimensionality and its assessment. Journal of Marketing Research, 2(25), 186-192.

Government Office of Vietnam 2016, Government Office of Vietnam Homepage, 21/03/2016. Available from: http:// vpcp.chinhphu.vn/Home/Chuan-bi-trinh-Quoc-hoi-phe-chuan-Hiep-dinh-TPP/20163/18252.vgp. (30 April 2016).

Henley, A. (2007). Entrepreneurial aspiration and transition into self-employment: evidence from British longitudinal data. Entrepreneurship and Regional Development, 19(3), 253-280.

Khuong, M. N., \& An, N. H. (2016). The factors affecting entrepreneurial intention of the students of Vietnam national university - a mediation analysis of perception toward entrepreneurship. Journal of Economics, Business and Management, 4(2), 104-111.

Kolvereid, L. (1997). Prediction of employment status choice intentions. Entrepreneurship Theory and Practice. 21, 47-57.

Krueger, N. F., \& Carsrud, A. L. (1993). Entrepreneurial intentions: applying the theory of planned behaviour. Entrepreneurship \& Regional Development, 5(4), 315-330.

Krueger, N. F. J., \& Brazeal, D. V. (1994). Entrepreneurial potential and potential entrepreneurs. Entrepreneurship Theory and Practice, 18(3), 91-104.

Krueger, N. F., Jr., Reilly, M. D., \& Carsrud, A. L. (2000). Competing models of entrepreneurial intentions. Journal of Business Venturing, 15, 411-432.

Laspita, S., Breugst, N., Heblich, S., \& Patzelt, H. (2012). Intergenerational transmission of entrepreneurial intentions. Journal of Business Venturing, 27(4), 414-435. doi:10.1016/j.jbusvent.2011.11.006.

Lee, L., Wong, P. K., Foo, M., \& Leung, A. (2011). Entrepreneurial intentions: the influence of organizational and individual factors. Journal of Business Venturing, 26, 124-136.

Liñán, F., \& Chen, Y.-W. (2009). Development and cross-cultural application of a specific instrument to measure entrepreneurial intentions. Entrepreneurship: Theory \& Practice, 33(3), 593-617. doi:10.1111/j.1540-6520.2009.00318.x.

Linan, F, Rodriguez-Cohard, JR, Rueda-Cantuche, JMR. (2005). Factors affecting entrepreneurial intentions levels. Paper presented at the 45th Congress of the European Regional Science Association, Amsterdam.

Linón, F., Nabi, G., \& Krueger, N. (2013). British and spanish entrepreneurial intentions: a comparative study. La Intención Emprendedora En Reino Unido Y España: Un Estudio Comparativo, 33, 73-103.

Llouga, S. N., Nyock, A. C., \& Hikkerova, L. (2013). Influence des perceptions sociales sur l'intention entrepreneurial des jeunes. (French). The impact of social perceptions on the entrepreneurial intention of the young people. (English), 31(5), 115-130.

Ministry of Industry and Trade of Viet Nam 2016, Introduction of Main Issues of the TPP. Available from: http://tpp.moit gov.vn/?page=tpp\&parent=Giới\%20thiệu\%20về\%20các\%20nội\%20dung\%20ch\%C3\%ADnh\%20của\%20Hi ệp\%20định\%20TPP\&info=on\&dir=about. (30 April 2016).

Moriano, J. A., Gorgievski, M., Laguna, M., Stephan, U., \& Zarafshani, K. (2012). A cross-cultural approach to understanding entrepreneurial intention. Journal of Career Development (Sage Publications Inc.), 39(2), 162-185. doi: $10.1177 / 0894845310384481$

Nyock, A. C., llouga, S. N., \& Hikkerova, L. (2013). Intention entrepreneuriale et projet professionnel. (French). Entrepreneurial Intention and Choice of Occupation. (English), 30(4), 47-65.

Paço, A., Ferreira, J., Raposo, M., Rodrigues, R., \& Dinis, A. (2011). Behaviours and entrepreneurial intention: empirical findings about secondary students. Journal of International Entrepreneurship, 9(1), 20-38. doi:10.1007/s10843-010-0071-9.

Pham, Yen. (2016). The TPP-Opportunities-Challenges and Strategic Sollutions, Ministry of Industry and Trade of Viet Nam. Available from: http://tpp.moit.gov.vn/App_File/TPP/about/Hiep\%20dinh\%20TPP\%20\%20Co\%20hoi\%20Thach\%20thuc\%20va\%20Giai\%20phap\%20chien\%20luoc.pdf. (30 April 2016).

Pihie, Z. A. L. (2009). Entrepreneurship as a career choice: an analysis of entrepreneurial self-efficacy and intention of university students. European Journal of Social Sciences, 9(No. 2), 338-349. 
Raijman, R. (2001). Determinants of entrepreneurial intentions: Mexicans immigrants in Chicago. Journal of Socio-Economics, 30(5), 393.

Robledo, J., Vallespín Arán, M., Martin Sanchez, V., \& Rodríguez Molina, M. (2015). The moderating role of gender on entrepreneurial intentions: a TPB perspective. Intangible Capital, 11(1), 92-117. doi:http://dx.doi.org/10.3926/ic.557.

Shapero, A. (1975). The displaced, uncomfortable entrepreneur. Psychology Today, 9(6), 83-88.

Siu, W.-S., \& Lo, E. S.-c. (2013). Cultural contingency in the cognitive model of entrepreneurial intention. Entrepreneurship: Theory \& Practice, 37(2), 147-173. doi:10.1111/j.1540-6520.2011.00462.x.

Souitaris, V., Zerbinati, S., \& Al-Laham, A. (2007). Do entrepreneurship programmes raise entrepreneurial intention of science and engineering students? The effect of learning, inspiration and resources. Journal of Business Venturing, 22(4), 566-591. doi:10.1016/j.jbusvent.2006.05.002.

St-Jean, É., Nafa, A., Tremblay, M., Janssen, F., Baronet, J., \& Loué, C. (2014). Entrepreneurial intentions of university students: an international comparison between African, European and Canadian students. International Journal of Entrepreneurship \& Innovation Management, 18(2/3), 95-114. doi:10.1504/IJEIM.2014.062878.

Tegtmeier, S. (2006). Explaining individual entrepreneurial intentions: the theory of planned behavior as a socialpsychological model in the context of entrepreneurship. NeuroPsychoEconomics Conference Proceedings, 1(1), 22-22.

Tegtmeier. (2012). Empirical implications for promoting students's entrepreneurial intentions. Journal of Enterprising Culture, 20(No. 2), 151-169.

Thompson, E. R. (2009). Individual entrepreneurial intent: construct clarification and development of an internationally reliable metric. Entrepreneurship Theory and Practice, 33(Issue 3), 669-694.

Tkachev, A., \& Kolvereid, L. (1999). Self-employment intentions among Russian students. Entrepreneurship and Regional Development, 11(3), 269-280.

Tomski, P. (2014). Entrepreneurial intentions of management students as roots for new ventures. Empirical investigation. Problems of Management in the 21st Century, 9(1), 84-94.

Tounés, A. (2006). L'intention entrepreneuriale des étudiants : le cas français. (French). Entrepreneurial Intention of Students: The French Case. (English), 219, 57-65.

Tran, H. T., \& Santarelli, E. (2014). Capital constraints and the performance of entrepreneurial firms in Vietnam. Industrial \& Corporate Change, 23(3), 827-864.

Turker, D., \& Sonmez Selcuk, S. (2009). Which factors affect entrepreneurial intention of university students? Journal of European Industrial Training, 33(2), 142-159.

Van Gelderen, M., Brand, M., Van Praag, M., Bodewes, W., Poutsma, E., \& van Gils, A. (2008). Explaining entrepreneurial intentions by means of the theory of planned behaviour. Career Development International, 13(6), 538-559.

Varela Villegas, R., Martínez Romero, A. C., \& PeÑA Guevara, A. T. (2011). Intención De Los Estudiantes De La Universidad Icesi Hacia La Creación De Empresa. (Spanish).

Wu, S., \& Wu, L. (2008). The impact of higher education on entrepreneurial intentions of university students in China. Journal of Small Business and Enterprise Development, 15(4), 752-774.

Wei, L. I. (2007). Ethnic entrepreneurship: studying Chinese and Indian students in the United States. Journal of Developmental Entrepreneurship, 12(4), 449-466.

Yang. (2013). The theory of planned behavior and prediction of entrepreneurial intention among Chinese undergraduates. Social Behavior and Personality, 41(3), 367-376.

Zhang, P., Wang, D. D., \& Owen, C. L. (2015). A study of entrepreneurial intention of university students. Entrepreneurship Research Journal, 5(1), 61-82

Submit your manuscript to a SpringerOpen ${ }^{\circ}$ journal and benefit from:

- Convenient online submission

- Rigorous peer review

- Immediate publication on acceptance

- Open access: articles freely available online

- High visibility within the field

- Retaining the copyright to your article

Submit your next manuscript at $>$ springeropen.com 